DOI 10.52575/2712-7451-2021-40-4-534-544

\title{
Экспериментальное исследование дискурсивного поля имени
}

\author{
Позднякова Е.Ю. \\ Алтайский государственный технический университет им. И.И. Ползунова, \\ Россия, 656038, г. Барнаул, пр. Ленина, 46 \\ E-mail: helena_poz@mail.ru
}

\begin{abstract}
Аннотация. Собственное имя рассматривается автором как свернутый текст, который может быть развернут в процессе его восприятия реципиентом. С целью доказательства гипотезы о том, что имя заключает в себе многослойную информацию, образующую дискурсивное поле онима, был проведен ассоциативный эксперимент. В результате эксперимента было получено 5500 реакций, среди которых выделяются как частотные (стереотипные) реакции, составляющие ядро ассоциативного поля онима, так и низкочастотные (единичные) реакции, представляющие его периферию. Коммуникативные тактики реципиентов разделены в ходе анализа на оценочные, атрибутивные, номинативные, предикативные, локативные и пропозиционные. Движение от онима к дискурсу происходит поэтапно, от онима через совокупность личностных смыслов - к ассоциативному фону имени, далее - к диалогическим, либо монологическим высказываниям, образующим дискурсивное поле онима.
\end{abstract}

Ключевые слова: собственное имя, оним, дискурс, текст, дискурсивное поле, ассоциативный эксперимент

Для цитирования: Позднякова Е.Ю. 2021. Экспериментальное исследование дискурсивного поля имени. Вопросы журналистики, педагогики и языкознания, 40 (4): 534-544. DOI: 10.52575/27127451-2021-40-4-534-544

\section{Experimental Study of the Discursive Field of a Proper Name}

\author{
Elena Yu. Pozdnyakova \\ Polzunov Altai State Technical University, \\ 46 Lenina Pr, Barnaul 656038, Russian Federation \\ E-mail: helena_poz@mail.ru
}

\begin{abstract}
In the article, the proper name is considered as a compressed text that can be expanded in the process of its perception by the recipient. The associative experiment was conducted in order to prove the hypothesis that the proper name contains a multi-layered information that forms the discursive field of the proper name and can be identified through the associative background of the onym. As a result of the experiment, 5500 reactions were received. Among them there are both frequency (stereotypical) reactions that make up the core of the associative field of the onym, and low-frequency (single) reactions that represent its periphery. Nuclear associations reflect stereotypical reactions characterized by repeatability and reproducibility. Individual reactions are connected with the personal meanings of the recipients. The communicative tactics of the recipients were divided into evaluative, attributive, nominative, predicative, locative and propositional. The resulting reactions are the chains of meanings. At this stage, the initial expending of the discursive field of the onym takes place - from the proper name to a set of keywords or elementary statements. The discourse is developed through an associative-verbal network that creates an associative background of the name, and the name itself is represented as a kind of "bundle of meanings" enclosed in a linguistic form. The activity of the perceiving subject can be considered as a speechthinking activity aimed at expending of the discourse of the onym, and the processes of perception are oppositely directed to the processes of nomination. The movement from the onym to the discourse is gradual. Itstarts from the onym, proceeds through a set of personal meanings - to the associative
\end{abstract}


background of the proper name, then results in dialogical or monological statements that form the discursive field of the onym.

Keywords: proper name, onym, discourse, text, discursive field, associative experiment

For citation: Pozdnyakova E.U. 2021. Experimental Study of the Discursive Field of a Proper Name. Issues in Journalism, Education, Linguistics, 40 (4): 534-544 (in Russian). DOI: 10.52575/2712-74512021-40-4-534-544

\section{Введение}

Цель статьи - описать результаты проведенного ассоциативного эксперимента и доказать, что имя представляет собой свернутый текст, который может быть развернут в процессе его восприятия реципиентом.

В работах отдельных исследователей уже высказывались мысли об ониме как свернутом тексте [Мурзин, Штерн, 1991; Горбаневский, 1994; Михайлюкова, 2014; Степовая, 2014; Максимов, 2015; и др.], однако законченной теории дискурсивной природы имени не существует. Мы предлагаем новый, дискурсивный подход к собственному наименованию, который предполагает взгляд на оним «как на своеобразный редуцированный до одного слова (или словосочетания) текст, эксплицированный в дискурсе и направленный от номинатора к реципиенту, строящийся по единым коммуникативным законам, определенным образом структурированный, заключающий в себе разнообразную информащию и обладающий определенной семантикой» [Позднякова, 2021, с. 250]. Дискурсивность онима понимается как включенность собственного имени в коммуникативные процессы, и синхронные, и диахронные, способность вовлекать в процессе функционирования различные экстралингвистические данные, связанные с субъективным восприятием адресата и завязанные на понимание онима. Все эти данные, вся информация, вовлеченная, как в орбиту, в дискурсивное поле онима, способны аккумулироваться в пределах лексической единицы и воспроизводиться/разворачиваться в процессе коммуникации в языковом сознании носителей языка. Как отмечает Н.Н. Шпильная, «именно лексема, будучи свернутым текстом, служит “точкой входа" в ментальные структуры - в текстовое пространство языкового сознания, представленного текстами-примитивами - совокупностью ключевых слов как коммуникативных фрагментов» [Шпильная, 2014, с. 321].

Дискурсивное поле имени включает в себя различные уровни, связанные с процессами восприятия онима и с процессами речепорождения. По нашему убеждению, любое собственное имя заключает в себе многослойную информацию, которая, в том числе, может быть выявлена через ассоциативно-вербальную сеть, провоцируемую онимом.

Основываясь на предположении, что имя актуализирует дискурс, стоящий за онимом, мы построили следующую модель дискурсивного эксперимента:

1 этап - ассоциативный эксперимент (АЭ). АЭ необходим для актуализации ассоциативно-когнитивного уровня восприятия онима. Результатом АЭ должен явиться набор ключевых слов, моделирующих концепт имени. Дискурс на данном этапе развертывается через ассоциативно-вербальную сеть, создающую ассоциативный фон имени.

2 этап - моделирование диалогического текста. Результатом моделирования является конструируемая речь - заданный онимом диалогический дискурс.

3 этап - моделирование монологического текста. Результатом моделирования должны стать смоделированные фантазийные монологические дискурсы, в которых разворачивается оним.

\section{Результаты ассоциативного эксперимента}

С целью доказательства гипотезы о том, что имя заключает в себе многослойную информацию, которая образует дискурсивное поле онима и может быть выявлена через 
ассоциативный фон имени, был проведен свободный ассоциативный эксперимент. Стимулами послужили 20 наименований коммерческих предприятий г. Барнаула, а именно: 10 названий магазинов и торговых центров (Светофор, Малина, Лето, Волна, Весна, Магнит, Пчелка, Простор, Галактика, Арена) и 10 названий предприятий ресторанной сферы (Черемушки, Облепиха, Лукошко, Асадор, Опера, Сова, Тициан, Океан, Иероглиф, Ганс). Данные названия были выбраны методом случайной выборки, вид деятельности предприятия в анкете не был указан. Испытуемым (170 студентам 1 курса АлтГТУ им. И. И. Ползунова) предлагалось написать все возможные ассоциации, возникшие при восприятии указанных слов. В ходе эксперимента было получено более 5500 реакций, среди которых выделяются как частотные (стереотипные) реакции, составляющие ядро ассоциативного поля онима, так и низкочастотные (единичные) реакции, представляющие его периферию. В 65 случаев отмечается отсутствие ассоциаций. Наиболее значимыми при описании ассоциативного поля онима признаются высокочастотные реакции, поскольку «ядро (частотная часть) поля устойчиво во времени, содержит реакции, обладающие узуальными связями со словом-стимулом» [Гуц, 2005, с. 39].

Рассмотрим полученные в результате свободного ассоциативного эксперимента наиболее частотные реакции.

Светофор - зеленый / зеленый свет / зеленый цвет (36), дорога/дороги (32), красный / красный свет (31), желтый (24), перекресток (15), пешеходы/пешеход (14), магазин / бюджетный магазин (12/1), машины/машина (13), регулировщик / регулирование / регулировщик движения / регулировщик движения на дороге / регулирование движения на дорогах / регулирующий светофор (8/1), пешеходный переход / дорожный переход / переход / безопасный переход (3/1/5/1), автомобиль/автомобили (8), стоп (7), ПДД (6), движение (6), опасность (5), правила (5), город (5), авария (4), зебра (4), пробки/пробка (4), сигналы/сигнал (4), столб (3), предупреждение (3), свет (3), дешево (2), разноцветный/разноцветность (2), ожидание / режим ожидания (2), радуга (2), безопасность (2), металл (2), цвета/цвет (2), люди (2), сериал по СТС / сериал (2), (всего 328 ассоциаций, из них 46 единичных).

Малина - ягода / ягоды / лесная ягода (41), варенье (34), лето (25), сладость / сладко / сладкая / сладость / сладкий вкус / сладкая ягода (15/2/1), дача (17), куст / кусты / большой куст (11/1), вкусно/вкусная (10), красный цвет / красная (7), компот (6), чай / чай с малиной / чай с ягодой (6), лес (5), медведь (5), торговый центр/ТЦ/ТРЦ (5), с шипами / шипы (5), клоп / клопы / с клопами (3/1), колючки/колючая (4), огород (4), огород / бабушкин огород (3/1), пчела/пчелы (3), розовая (3), деревня (3), простуда (3), сироп (2), сад (2), цвет (2), калина (2), комары (2), жуки/жучки (2), ведро/ведерко (2), садовая (2), закат (2), витамины (2), малиновый цвет (2), морс (2) (300 реакций, из них 52 единичных).

Лето - жара/жарко/жаркое/жара +30 / жаркая погода (2), (36/2), яркое солнце / солнце (34), отдых / долгожданный отдых (23/1), море (17), тепло (17), каникулы (16), пляж (13), речка/река (12), огород (8), загар (7), время года (6), дача (6), отпуск (6), комары (6), прогулки/прогулка (6), песок (5), друзья (5), сессия (6), купание на озере / купание в озере / купание / купаться (2 / 2/ 1), весело/веселье (5), трава (4), озеро (3), купальник (3), мороженое (3), велосипед (3), шашлык (3), рыбалка (3), поход (2), зима (2), гроза (2), радость (2), путешествия (2), энергия (2), ягоды (2), пот (2), поездки (2), зелень (2), день рождения (2) (365 реакций, из них 79 единичных).

Волна - море (34), серфинг/серф/серф-борд (27/2/1), океан (14), вода (13), ветер (10), пляж (9), цунами (8), корабли / корабль (7), прибой (6), радио волна / радио (5), ТРЦ Волна / ТРЦ / торговый центр (5), шторм (5), звук (4), красиво/красота (4), песок (4), пена (4), синий/синяя (4), берег (4), солнце (4), брызги (3), морские / речные волны / речная волна (3), отдых (3), скала/скалы (3), страх (3), шум (3), успокоение/спокойствие (3), свет (2), цвет (2), Ашан (2), дельфины (2), движение (2), речка/река (2), лодка (2), прилив (2), голубой (2), отпуск (2), сёрфер (2), чайки (2), энергия (2) (292 реакции, из них 74 единичных). 
Весна - тепло / теплая / теплая погода (19/1), цветы/цветочки (17), грязь (13), лужи (12), солнце/солнышко (11/1), трава / зеленая трава (10/1), подснежники/подснежник (10), птицы / птички (10), почки деревьев / почки (1/7), ручейки / ручьи /ручеек (8), хорошее время года / время года (8), таяние снега / тает снег / таяние (2/5), немного слякоти /слякоть (7), зелень (5), цветение (5), аллергия (4), любовь (4), оживление природы / пробуждение природы / пробуждение (2 / 2), праздники (4), сирень (4), дождь/дожди (3), торговый центр / ТЦ (3), листья/листы/листики (3), насекомые (3), проталина/проталины (3), верба (2), запах (2), снег (2), красивая / красота (2), Наурыз (2), сакура (2), оттепель (2), капель (2), скоро лето (2), ростки (2), черемуха (2), берёзовый сок (2), влажный воздух (2), пение птиц (2), осень (2), зима (2), лето (2), Пасха (2), жизнь (2), май (2), романтика (2), экзамен/экзамены (2), день энергетики / день рождения (2) (319 реакций, из них 85 единичных).

Магнит - притяжение (30), магазин / продуктовый магазин (27), полюс / полюса / два полюса (14/2), металл (16), физика (15), железо / железная руда (12/1), холодильник (12), поле / магнитное поле / электромагнитное поле (8/1/1), красный, синий (6) / красносиний (2), компас (7); катушка (5), сувенир на холодильник / сувенир (1/4), ток / электрический ток / электричество (2/1/1), синий цвет / синий (3); на холодильник / магнитик на холодильнике / висит на холодильнике (2/1), юг (3); полярность (3), северный и южный полюс (3); индукция / электромагнитная индукция (2), иголки/игла (2), плюс/минус (2), руда (2), магнетизм (2), притягивать/притягивание (1/1), красный цвет (2), сеть магазинов (2), притягивает железо / предмет притягивающий железо (2), девушка / красивая девушка на улице (2), север (2), путешествия (2), подарок (2), отталкивание (2), отдых (2), сопротивление (2), продукты (2), сеть супермаркетов / супермаркет (2), волны (2) (261 реакция, из них 40 единичных).

Пчелка - мёд (57), улей/улики/ульи (33), жало (19), соты (18), цветы/цветок/цветочек (17), жужжание/жужжать/жужжащая (11), насекомое (10), пасека (10), укусы/укус (9), конфета/конфеты/конфетка (9), жёлтый / желтая / желтый цвет (8), полоски / полосатая / полосатый раскрас (5/1), черно-желтый/желтый, черный/желтая, черная / жёлточёрного цвета / черно-жёлтая расцветка (7), пыльца (7), Майя (5), больно/боль (5), опылять / опыление / опыление цветов (4/1), труженик/труженица/трудяга (5), нектар (5), «Билайн» (4), лето (4), рой (3), трудолюбие (3), аллергия / аллергия на пчел у меня и у мамы (3), труд (3), весна (2), маленькая пчела (2), матка (2), медведь (2), опухоль после укуса (2), оса (2), черный (2), полет (2), пчеловод (2), воск (2) (317 реакций, из них 31 единичных).

Простор - свобода / ощущение свободы (40/1), поле / поля / красивое зеленое поле (33/1), пространство (9), бескрайняя степь / бескрайние степи / степь (8), воля (8), небо / небеса / чистое небо / голубое небо (6/1/1/1), горизонт (7), ветер в поле / ветер (6), воздух / чистый воздух (4/2), горы (6), луг/луга (6), торговый центр / ТЦ (5), магазин (5), природа (4), раздолье (4), широта/ширь/обширно (3/1), равнина (4), комфорт (3), личное пространство (3), место (3), пустота (3), Россия/Русь (2/1), трава (3), безграничность (2), большой (2), даль (2), дорога / широкая дорога (2), душа (2), эхо (2), леса/лес (2), лилии (2), море (2), мысли (2), океан (2), полет (2), тайга (2), холл (2), границы (2) (278 реакций, из них 64 единичных).

Галактика - космос (39), звезды (35), планеты/планета (25), Вселенная (20), Млечный путь (17), бесконечная/бесконечность (15), торговый центр / ТЦ /ТРЦ / торговый центр в Барнауле / торговый центр с любимыми магазинами (12/1), неизвестность неизвестная (6/1), кометы/комета (5), чёрные дыры / Черная дыра (5), Солнце (5), магазин (4), метеоры/метеориты (4), загадка/загадочность (2/1), созвездия (3), космонавт (3); простор (3), ракеты/ракета (3), тайна/таинственность (2/1), тьма/темнота (3), холод (3), Андромеда (2), безграничность / безграничное пространство (2), звездная пыль / пыль (2), Земля (2), бездна со множеством звезд / бездна (1/1), Луна (2), спираль (2), телескоп (2), астроном (2), мир (2), множество планет и звезд, которые скопились в одном месте / скопление звезд (2); необъятно/необъятность (2), НЛО (2), Орион (2), коллапс (2) (295 реакций, из них 47 единичных). 
Арена - гладиатор/гладиаторы (29), цирк (23), торговый центр / ТЦ / ТРЦ / торговый центр в Барнауле / торговый центр Арена/ ТЦ очень далеко (20), бой / бои / бои без правил (17/1), манеж (10), Колизей (9), Рим / Римская империя (8/1), кровь (7), сцена (7), выступления/выступление (6), клоун (6), спорт (6), битва (5), соревнования/соревнование (5), сражение (5), шоу (4), стадион (4), смерти/смерть (4), львы/лев (3), развлечение (3), трибуна/трибуны (3), поле / огромное футбольное поле / футбольная арена (2/1), колесница / колесницы (3), люди / много людей / большое количество людей, (2/1), гладиаторская арена (3), боль (2), большой/большая (2), зрители (2), слава (2), Спарта (2), магазин (2), концерт (2), круг/круглая (2), состязание (2), поединок (2) (280 реакций, из них 62 единичных).

Черемушки - микрорайон / район / райончик / район города / район Барнаула / название одного из районов Барнаула (23/1), ягода/ягоды (18), деревня / деревенька / деревня какая-то (19), дерево / деревья / дерево черёмуха (14/1), черемуха (8), нет ассоциаций (6), магазин / магазин выпечки (5/1), кафе (5), варенье (4), село (4), цветы/цветочки (3/1), новостройка/новостройки (4), конфеты/конфета (4), посёлок (4), весна (3), запах (3), детский танцевальный ансамбль / хореографический коллектив / ансамбль (1/1/1), лето (3), лес (3), черная кисть / чёрная / черный (1/2), садоводство/сад /сады (1/2), название улицы / улица (3), чай (2), музыкальная группа (2), населённый пункт / название населенного пункта (2), заведение (2), кофе (2), цветение (2), хлебопекарня / пекарня (2), (199 реакций, из них 48 единичных).

Облепиха - ягода/ягоды (41), кислый / кислая / кисло / кислота / кислятина / кислость/ кислый вкус / кислая ягода (24/1/1), оранжевый / оранжевая / оранжевый цвет (22), варенье / варенье из облепихи (20/1), куст/кусты (11), дерево / садовое дерево (9/1), сок / облепиховый сок (7/1), дача (6), ветка/ветки (6), масло (6), колючки/колючая/колючка (2/2/1), морс (5), компот (5), чай / возможно чай (4/1), лето (5), Алтай / Алтайский край (4/1), жёлтый / желтый цвет (4), деревня (3), осень (3), растение (3), лес (3), лекарство / народные лекарства (2/1), сад (3), невкусно / очень невкусный вкус (2/1), косточки/косточка (2), лечение (2), противный (2), сладость/сладкая (2), еда (2), желе / вкусное домашнее желе (2), кислые оранжевые ягоды / оранжевая ягодка формы эллипсоида, кисловатая на вкус (1/1) (260 реакций, из них 34 единичных).

Лукошко - корзина / корзинка / корзинка для сбора каких либо растений (46/1), гриб/грибы/грибочки (39), ягоды/ягода (29), лес (18), сказка/сказки (14), плетёная корзина / плетеное / плетенка / плетение (3/5), береста (7), пирожки/пироги (6), старина/старость/старое (1/2/1), семейное кафе / кафе (2/2), деревня (3), Лукашенко (3), Русь (3), сбор / собирательство (2/1), ведро/ведерко (3), медведь (3), бабушка (3), малина (2), опушка (2), ежик (2), волк (2), лиса (2), дача (2), девочка (2), еда (2), плетеная сумка (2), лето (2), малина (2), корзинка для грибов и ягод / корзинка для сбора ягод/грибов (2), прутья (2), Красная шапочка (2) (270 реакций, из них 45 единичных).

Асадор - ресторан / ресторан в Барнауле (25/1), нет ассоциаций (18), еда (10), Испания (9), не знаю / неизвестно / неизвестность / не представляю, что это (8/1/1), мясо (6), блюдо (4), гриль (4), кафе (4), сад (4), огонь/костер (3), мангал (3), противень (3), Япония (3), испанский (3), вертел (2), жарить (2), телевидение (2), дорамы/дорама (2), друзья/ дружба (2), Италия (2), кухня (2), напитки (2), вечер (2), уют (2), стейк хаус (2) (196 реакций, из них 64 единичных ).

Опера - театр (31), музыка (17), клуб / ночной клуб / клуб в Барнауле / клуб-бар (16), пение (15), искусство (10), браузер (9), сцена (8), голос (7), песня / песни (7), оркестр (6), балет (6), певец /певцы (6), культура (5), бар (4), ария (4), вокал (4), спектакль (4), танцы (3), богатые зрители / зрители (3),красота (3), бинокль (3), певица / оперная певица (3), сотрудники оперативного отдела / оперуполномоченный (2/1), представление (3), костюмы / костюм (3), мыльная / мыльная опера / мыло (2/1), концерт (3), артисты (2), зал (2), Евгений Онегин (2), выступление (2), поющие люди / поют люди (2), интеллигентность / интеллигент (2), мюзикл (2), история (2) (272 реакции, из них 70 единичных). 
Сова - птица (45), ночь (42), лес (22), мудрость (14), мышь/мыши (14), глаза / глаз / большие глаза (12/1), хищник (9), деревья/дерево (6), сон (5), филин (5), дупло (4), Гарри Поттер (4), охота (3), спокойствие (3), поворачивает голову на 360 градусов / 360 / 360 градусов (3), полет (3), бесшумно летает (3), у-у / угу / ууу-ууу (3), бессонница (3), человек, который поздно ложится и поздно встает / человек который ведет ночной образ жизни / люди, которые не спят ночью (3), сонливость (2), жаворонок (2), большая птица (2), уханье (2), ум/умная (2), перья (2), питается мышами (2), поворачивает голову на 270 градусов (2), Винни пух (2), крылья (2), красота (2), ночная / ночная птица (2), темнота (2), человек (2), клюв (2), страх (2), перья (2); 180 градусов (2), острые когти / когти (1/1) (296 реакций, из них 51 единичных).

Тициан - художник (18), Микеланджело (3), Италия (17), живопись (15), картины/картина (12), живописец (11), нет ассоциаций (11), искусство (7), ресторан (5), эпоха Возрождения / Возрождение (5), портрет/портреты (4), краски (4), либо цветок / возможно цветок / цветок (3/1), цвет/цвета (4), Венера / Венера Урбинская (3/1), кофейня (4), кисть (3), кофе (2), не знаю (2), Рим (2), имя (2), писатель картин (2), растение (2), полотно (2), птица (2), Леонардо / Леонардо да Винчи, (2), чай (2), человек (2) (209 реакций, из них 59 единичных).

Океан - волны/волна (22), вода (19), рыба/рыбы (16), корабль/корабли (15), кит/киты (11), акула/акулы (11), глубина/глубоко/глубокий, (9/1/1), шторм (8), море/моря (7), свобода (7), отдых (7), Тихий (6), пляж (5), умиротворение (4), много морепродуктов / морепродукты (4), простор (7), неизведанный/неизведанное (4), красоты/красота (4), острова/остров (4), солёная вода (4), чайка/чайки (4), закат (4), бескрайний / бескрайность / бескрайняя водная гладь (4/1), много воды / очень много воды / большое количество воды (3/1), синий/синева (3/1), дельфины/дельфин (3), соль (2), мировой океан / мировой (2), 5 (2), голубой цвет / голубой (2), бескрайние просторы / бескрайние водные просторы (2), мечта (2), Марианская впадина (2), широта/широкие (2), цунами (2), прибой (2), бриз (2), свежесть (2), большой (2), шум (2), загрязнение (2), песня (2), магазин / магазин с морепродуктами (2), Титаник (2), спокойствие/спокойный (2), объем (2), страх (2), лед (2), осьминог (2) (308 реакций, из них 62 единичных).

Иероглиф - Китай (32), знак / знаки / письменный знак (21/2), Египет / древний Египет (21), символ / символы (19), письменность (14), Япония (13), древность / древний (11), буквы/буква (5), письма / письмо / тип письма (5/1), каллиграфия (6), язык / другой язык (4/1), Восток / восточные страны / Дальний Восток (3/1/1), рисовать / рисунок (4), свиток (2), Восточная Азия / Азия (1/3), алфавит (4), искусство (4), черным по глине (2), пирамида / пирамиды (4), слова / слово (4), загадка (4), татуировка / тату (3/1), руна / руны (3), Корея (3), непонятный / непонятность (3), ресторан / ресторан японской кухни (3/1), мой почерк / почерк / красивый почерк (2/1), Рим / Древний Рим (2), тайна (2), смысл (2), каракули (2), надпись (2), фараон (2), глиняные таблички / табличка (2) (282 реакции, из них 56 единичных).

Ганс - Христиан Андерсен / Андерсен (15/8), имя / немецкое имя / иностранное имя (21), Германия (17), писатель (13), сказки / сказка (11), немец / немцы (11), бар / бар в Барнауле (8/1), остров (7), пиво/пивко (7/1), нет ассоциаций (6), поэт (4), утенок / «Гадкий утенок» (4), Дюймовочка (3), лошадь (3), персонаж сказки / персонаж / вымышленный персонаж (2/1), человек (2), мужчина (2), магазин (2), фамилия (2), детство (2), Европа (2), сказочник (2), заведение в городе (2), фильм / кино (2), учёный (2), кинорежиссёр (2), кафе (2), книги (2) (239 реакций, из них 70 единичных).

Полученные реакции, в соответствии с классификацией Ю.Н. Караулова [1999, c. 108], можно разделить на пять коммуникативных тактик: предикацию (в узком смысле как приписывание признака предмету), номинацию (в том числе дефиницию), локацию, оценку и пропозицию. Основываясь на данных коммуникативных тактиках, мы выделили следующие типы реакций: оценочные, атрибутивные, номинативные, предикативные, локативные и пропозиционные. 
Перечисленные типы реакций испытуемых могут быть разделены на следующие оппозиции:

а) атрибутивные - адвербиальные;

б) номинативные - предикативные;

в) локативные - темпоральные;

г) кроме того, все полученные реакции можно разделить на нейтральные и оценочные, среди оценочных реакций выделяются высказывания с позитивной и негативной оценкой.

Примеры типов реакций испытуемых, разделенных на оппозиции, представлены ниже (см. таблицу).

Примеры типов реакций испытуемых

Examples of types of reactions of subjects

\begin{tabular}{|c|c|}
\hline Тип высказывания - примеры реакций & Тип высказывания - примеры реакций \\
\hline $\begin{array}{l}\text { Атрибутивные высказывания (какой?): } \\
\text { Малина - сладкая, вкусная, садовая, колючая и др.; } \\
\text { Иероглиф - непонятный; } \\
\text { Лето - долгое, жаркое, запоминающеееся; } \\
\text { Светофор - на высокой ножке, разноцветный; } \\
\text { Пчелка - жужжащая, полосатая; } \\
\text { Галактика - бесконечная; } \\
\text { Арена - круглая, большая; } \\
\text { Черемушки - черная, фиолетовый, сиреневый }\end{array}$ & $\begin{array}{l}\text { Адвербиальные высказывания (как?): } \\
\text { Светофор - дешево; } \\
\text { Малина - вкусно; } \\
\text { Лето - тепло; светло; жарко и не очень ком- } \\
\text { фортно; } \\
\text { Черемушки - вкусно; } \\
\text { Волна - мокро; } \\
\text { Простор - много; обширно }\end{array}$ \\
\hline $\begin{array}{l}\text { Номинативные высказывания (дефиниции и поясне- } \\
\text { ния): } \\
\text { Малина - ягода; } \\
\text { Ганс - писатель; } \\
\text { Иероглиф - знак, символ; } \\
\text { Океан - вода, волна, глубина; } \\
\text { Волна - вода, море; } \\
\text { Светофор - устройство; } \\
\text { Весна - время года; } \\
\text { Пчелка - насекомое, конфета; } \\
\text { Галактика - Вселенная, Млечный путь; торговый } \\
\text { центр; } \\
\text { Арена - иирк, манеж, стадион, магазин; } \\
\text { Черемушки - ягода, дерево, микрорайон }\end{array}$ & $\begin{array}{l}\text { Предикативные высказывания (словосочетания } \\
\text { и предложения): } \\
\text { Волна - можно долго за ними наблюдать, вол- } \\
\text { на набегает на берег; } \\
\text { Малина - растет у меня дома, дорого можно } \\
\text { продать;; } \\
\text { Светофор - жди, иди; } \\
\text { Весна - тает снег, день становится дольше; } \\
\text { сажать огород; готовиться к экзаменам; } \\
\text { преобладание желтого ивета в природе; } \\
\text { Магнит - притягивает железо; висит на холо- } \\
\text { дильнике; как притягивает, так и отталкива- } \\
\text { ет; привезен из отпуска }\end{array}$ \\
\hline $\begin{array}{l}\text { Локативные высказывания (где?): } \\
\text { Весна - рядом с Огнями; } \\
\text { Ганс - бар в Барнауле; } \\
\text { Волна - в ванной; } \\
\text { Магнит - у дома, на холодильник; } \\
\text { Арена - рядом, ТЦ очень далеко, ТЦ в Барнауле; } \\
\text { Черемушки - торговый центр в Камне-на-Оби; } \\
\text { Облепиха - Алтай; Алтайский край }\end{array}$ & $\begin{array}{l}\text { Темпоральные высказывания (когда?): } \\
\text { Волна - лето; } \\
\text { Весна - май; } \\
\text { Пчелка - лето; весна; } \\
\text { Простор - лето; } \\
\text { Галактика - будущее; вечность; } \\
\text { Арена - древность; } \\
\text { Черемушки - весна; лето; } \\
\text { Облепиха - осень; } \\
\text { Асадор - утро; вечер }\end{array}$ \\
\hline $\begin{array}{l}\text { Позитивные оценочные высказывания: } \\
\text { Весна - красота, хорошая погода; } \\
\text { Волна - спокойствие, красиво; } \\
\text { Лето - счастье; веселье; } \\
\text { Галактика - восхищение; } \\
\text { Малина - сладкая ягода; удовольствие }\end{array}$ & $\begin{array}{l}\text { Негативные оценочные высказывания: } \\
\text { Опера - отвращение; затянутость; } \\
\text { Океан - страх; } \\
\text { Простор - некачественное; } \\
\text { Пчелка - неприятно; слезы; боль; } \\
\text { Весна - грязь; } \\
\text { Светофор - опасность, авария, страх, смерть }\end{array}$ \\
\hline
\end{tabular}


В результате АЭ были получены реакции, позволяющие моделировать концепт имени, при этом ядерные ассоциации отражают стереотипные, повторяющиеся реакции, характеризующиеся повторяемостью и воспроизводимостью, а единичные реакции связаны с личностными смыслами реципиентов. Дискурс на данном этапе развертывается через ассоциативно-вербальную сеть, создающую ассоциативный фон имени, а сам оним представляется как некий «пучок смыслов», заключенный в языковую форму. Деятельность воспринимающего субъекта в таком понимании может быть рассмотрена как речемыслительная деятельность, направленная на разворачивание дискурса онима, причем процессы восприятия оказываются противоположно направленными процессам номинации.

\section{Свертывание/развертывание дискурса онима}

По справедливому замечанию Е.С. Кубряковой, «чтобы слово стало номинацией комплекса смутных идей, ассоциаций, представлений и т.п., оно должно быть «собрано» из неких идеальных семантических (содержательных) сущностей (признаков, множителей и т.д.). Однако, чтобы не остановить формирование мысли, а, напротив, стать толчком к ее дальнейшему развитию, оно должно тянуть за собой цепь новых ассоциаций и образов» [Кубрякова, 1986]. Слово, как «собираемая сущность» становится «отправной точкой для дальнейшего разворачивания и мысли, и речи» [Кубрякова, 1986, с. 59].

Данный процесс можно представить схематично (рис. 1).

Личностные смыслы (Н)

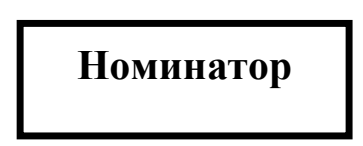

Дискурс 1

Ассоциативный фон имени (Н)
Личностные смыслы (Р)

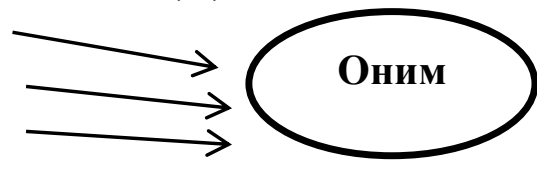

Дискурс 2

Рис. 1. Развертывание дискурса онима

Fig. 1. Unfolding an onym discourse

Итак, процесс развертывания дискурса онима включает в себя несколько этапов, отправной точкой в которых является речемыслительная деятельность номинатора, направленная на свертывание дискурса онима. Свертывание представляет собой процесс, противоположный развертыванию, однако необходимый в ходе выбора номинации для нового объекта. Номинатор, имеющий определенные интенции и мотивы номинации, знакомый с современными номинативными тактиками и дискурсивными практиками, выбирает (либо создает) наименование, которое наиболее коррелирует с его личностными смыслами (личностные смыслы Н) и вызывает у него определенные ассоциации (ассоциативный фон имени Н). Реципиент, воспринимая оним, пропускает его через свои собственные личностные смыслы (личностные смыслы Р), которые «высвечивают» наиболее важные для реципиента ассоциации (ассоциативный фон имени Р), на данном этапе еще смутные и зачастую невербализуемые, однако образующие некую ассоциативновербальную сеть, имеющую потенциал развертывания в монологический или диалогический дискурс.

Переход от личностных смыслов к ониму происходит последовательно: от номинатора через совокупность личностных смыслов $(\mathrm{H})$, через ассоциативный фон имени $(\mathrm{H})$, далее - к дискурсу онима (Д 1) и, через свертывание дискурса, - к результату данного процесса - наименованию (рис. 2). Ситуация номинации представляется нами как процесс выделения наиболее важной для номинатора информации из существующих и известных 
ему текстов-дискурсов с последующим максимальным их сгущением и преобразованием в единицу номинации (оним - слово или словосочетание).

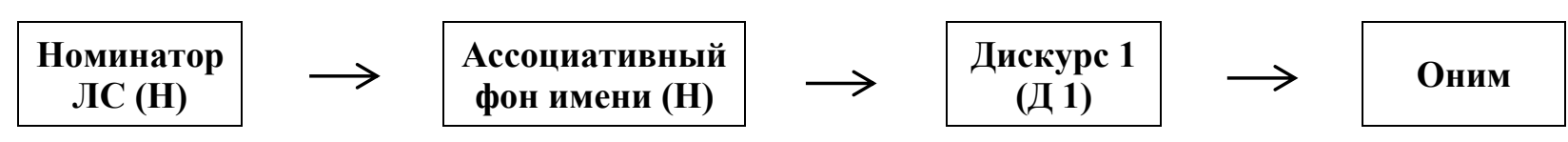

Рис. 2. Свертывание дискурса онима

Fig. 2. Collapsing onym discourse

Движение от онима к дискурсу в ходе его восприятия представляет собой процесс развертывания дискурса: от онима через совокупность личностных смыслов (Р) - к ассоциативному фону имени (Р), далее - к диалогическим либо монологическим высказываниям, образующим дискурс онима (Д 2) (рис. 3). При этом Д 1 может не совпадать с Д 2, поскольку те личностные смыслы, ассоциации и связанные с онимом с точки зрения номинатора дискурсы-тексты могут быть восприняты реципиентами (количество которых неограниченно) совершенно различно и развернуты в соответствии с собственными личностными смыслами и опытом воспринимающего субъекта. В процессе функционирования имена могут приобретать новые смыслы, поэтому зачастую те компоненты значения, которые вкладывались номинатором, в реальном употреблении могут искажаться, видоизменяться и даже утрачиваться, наполняя оним новыми смыслами и порождая новые тексты-дискурсы.

\begin{tabular}{|c|c|c|c|c|c|c|}
\hline Оним & $\longrightarrow$ & ЛС (P) & $\longrightarrow$ & $\begin{array}{c}\text { Ассоциативный } \\
\text { фон имени (Р) }\end{array}$ & $\longrightarrow$ & $\begin{array}{c}\text { Дискурс } 2 \\
\text { (Д 2) }\end{array}$ \\
\hline
\end{tabular}

Рис. 3. Развертывание дискурса онима

Fig. 3. Unfolding an onym discourse

\section{Заключение}

Проведенный на первом этапе исследования дискурсивной природы имени свободный ассоциативный эксперимент позволил получить ключевые ассоциации, связанные с концептом имени и образующие ассоциативно-вербальную сеть, создающую ассоциативный фон имени. В результате эксперимента были получены как частотные (стереотипные) реакции, составляющие ядро ассоциативного поля онима, так и низкочастотные (единичные) реакции, представляющие его периферию. Ядерные ассоциации отражают стереотипные реакции, характеризующиеся повторяемостью и воспроизводимостью, а единичные реакции связаны с личностными смыслами реципиентов.

Коммуникативные тактики реципиентов были разделены в ходе анализа на оценочные, атрибутивные, номинативные, предикативные, локативные и пропозиционные. Реакции испытуемых были сгруппированы в следующие оппозиции: а) атрибутивные - адвербиальные; б) номинативные - предикативные; в) локативные - темпоральные; г) нейтральные - оценочные. Среди оценочных реакций выделены высказывания с позитивной и негативной оценкой.

Рассматривая имя как свернутый текст, обладающий максимальной компрессией смысла, можно утверждать, что полученные реакции представляют собой цепочки смыслов, т.е. на данном этапе происходит первоначальное развертывание дискурсивного поля онима: от наименования - к набору ключевых слов, либо элементарных высказываний. Процесс развертывания дискурса онима включает в себя несколько этапов, отправной точкой в которых является речемыслительная деятельность номинатора, направленная на 
свертывание дискурса онима. Свертывание представляет собой процесс, противоположный развертыванию, однако необходимый в ходе выбора номинации для нового объекта. Мы предполагаем, что движение от онима к дискурсу происходит поэтапно, от онима через совокупность личностных смыслов - к ассоциативному фону имени, далее - к диалогическим, либо монологическим высказываниям, образующим дискурсивное поле онима.

\section{Список литературы}

1. Горбаневский М.В. 1994. Русская городская топонимия: проблемы историкокультурного изучения и современного лексикографического описания. Дис. ... докт. филол. наук. Москва, 432 с.

2. Гуц Е.Н. 2005. Психолингвистическое исследование языкового сознания подростка. Омск, Вариант-Омск, 260 с.

3. Караулов Ю.Н. 1999. Активная грамматика и ассоциативно-вербальная сеть. Москва, ИРЯ РАН, $180 \mathrm{c.}$

4. Кубрякова Е.С. 1986. Номинативный аспект речевой деятельности. Москва, Наука, 159 с.

5. Максимов В.О. 2015. Русский фамильный антропоним как свернутый текст и его лексикографическое описание. Вестник Российского университета дружбы народов. Серия: Русский и иностранные языки и методика их преподавания, 4: 83-89.

6. Михайлюкова Н.В. 2014. Тексты городских вывесок как особый речевой жанр (на материале языка г. Владивостока). Владивосток, Дальневост. федеральный ун-т, 190 с.

7. Мурзин Л.Н., Штерн А.С. 1991. Текст и его восприятие. Свердловск, Изд-во Урал. унта, $171 \mathrm{c}$.

8. Позднякова Е.Ю. 2021. К вопросу о дискурсивной теории ономастики. Культура и текст, 1(44): 245-261. DOI: 10.37386/2305-4077-2021-1-245-261. URL: https://journal-altspu.ru/wpcontent/uploads/2021/02/245-261.pdf (дата обращения: 26.05.2021).

9. Степовая О.А. 2014. Имя собственное как свернутый текст: к постановке проблемы. Филология и человек, 4: 127-130.

10. Шпильная Н.Н. 2014. Лексема и текст (к вопросу о деривационной корреляции). Проблемы истории, филологии, культурологии, 3(45): 320-322.

\section{References}

1. Gorbanevskiy M.V. 1994. Russkaya gorodskaya toponimiya: problemy istoriko-kul'turnogo izucheniya i sovremennogo leksikograficheskogo opisaniya [Russian urban toponymy: problems of historical and cultural study and modern lexicographic description]. Dis. ... doct. philol. sciences. Moscow, $432 \mathrm{p}$.

2. Guts E.N. 2005. Psikholingvisticheskoe issledovanie yazykovogo soznaniya podrostka [Psycholinguistic study of the linguistic consciousness of a teenager]. Omsk, Publ. Variant-Omsk, 260 p.

3. Karaulov Yu.N. 1999. Aktivnaya grammatika i assotsiativno-verbal'naya set' [Active grammar and the associative-verbal network]. Moscow, Publ. IRYa RAN, $180 \mathrm{p}$.

4. Kubryakova E.S. 1986. Nominativnyy aspekt rechevoy deyatel'nosti [The Nominative Aspect of Speech Activity]. Moscow, Publ. Nauka, 159 p.

5. Maksimov V.O. 2015. Russian family name as compressed text and its lexicographical description. Vestnik Rossiyskogo universiteta druzhby narodov. Russkiy i inostrannye yazyki i metodika ikh prepodavaniya, 4: 83-89 (in Russian).

6. Mikhaylyukova N.V. 2014. Teksty gorodskikh vyvesok kak osobyy rechevoy zhanr (na materiale yazyka g. Vladivostoka) [Texts of city signs as a special speech genre (based on the language of Vladivostok)]. Vladivostok, Publ. Dal'nevost. federal'nyy un-t, 190 p.

7. Murzin L.N., Shtern A.S. 1991. Tekst i ego vospriyatie [Text and its perception]. Sverdlovsk, Publ. Izd-vo Ural. un-ta, $171 \mathrm{p}$.

8. Pozdnyakova E.Yu. 2021. On the question of discursive theory of onomastics. Kul'tura i tekst, 1(44): 245-261 (in Russian). DOI: 10.37386/2305-4077-2021-1-245-261. Available at: https://journalaltspu.ru/wp-content/uploads/2021/02/245-261.pdf (accessed: 26.05.2021). 
9. Stepovaya O.A. 2014. Imya sobstvennoe kak svernutyy tekst: k postanovke problemy [Proper Name as a Condensed Text: Towards a Problem Statement]. Filologiya i chelovek, 4: 127-130.

10. Shpil'naya N.N. 2014. Lexeme and text (the question of correlation derivational). Journal of historical, philological and cultural studies, 3(45): 320-322 (in Russian).

Конфликт интересов: о потенциальном конфликте интересов не сообщалось.

Conflict of interest: no potential conflict of interest related to this article was reported.

\section{ИНФОРМАЦИЯ ОБ АВТОРЕ}

Позднякова Елена Юрьевна, доцент кафедры философии и социологии гуманитарного института Алтайского государственного технического университета им. И.И. Ползунова, г. Барнаул, Россия

\section{INFORMATION ABOUT THE AUTHOR}

Elena U. Pozdnyakova, Associate Professor of the Department of Philosophy and Sociology of the Humanitarian Institute of the I.I. Polzunova Altai State Technical University, Barnaul, Russia. 